\title{
Principles and Questions
}

\section{by W. Gunther Plaut}

I

When in 1985 I submitted my report Refugee Determination in Canada to the federal government, I made 89 separate recommendations. Of these, I consider five to have priority as the principles on which the whole process must rest if it is to be fair.

- Principle one: Refugees must have access to the process. Without access there can be no faimess. Any attempt to decide refugee claims by border officiales must be resisted.

- Principle two: The claim of the refugee must be heard by an independent Refugee Board. The number of members hearing the case is less important than that those hearing it be well-trained and totally independent in their judgment.

- Principle three: There must be an opportunity for a proper appeal. Every decent legal system provides for it, because human judgment is often faulty and a review will help to safeguard the accuracy of the decision and the faimess of the process by which it was reached. A proper appeal also means that appeal judges must be familiar with the special nature of refugee determination cases, with their often inaccessible human and factual components. Nothing exists in the domestic realm that compares with them.

- Principle four: The process must be expeditious. Judgment delays add an intolerable burden to the claimant as well as to the administration of justice.

- Principle five: The process of decision-making must be non-adversarial. Both state and claimant are there to arrive at the truth. The state should not try to prove the claimant wrong. A non-adversarial procedure will also more properly preserve the status of the claimant, who is not to be treated as a criminal. The way we arrive at the truth reflects on our own humanity.

The case of the 155 Tamils who appeared in lifeboats off the coast of Newfoundland illustrates the fact that these principles have so far not been clearly understood. Emotional discussions took place over the right or wrong of accepting these people into our refugee determination process -- when in fact the law gives us no options at all, and neither will the new legislation, if it incorporates the abovenamed five principles. The difference will be that the process will then be both fair and speedy; and, if it can be reduced to six months, the cost to the taxpayer will be relatively small, and so will the incentive to abuse the process.

\section{II}

It must not be denied that abuse of our determination system has lately grown to worrisome proportions. The most flagrant example is the recent arrival of thousands of Portuguese who, on landing, have claimed that they were Jehovah's Witnesses and were being persecuted in their homeland. When the claims reached unmanageable figures, the government introduced visa requirements for Portugal and thereby eliminated a good deal of the problem. Political considerations delayed speedier action and the addition of the Portuguese claims to the already large backlog of cases has threatened the integrity of the system.

Large sums have already been infused into the determination process, especially at the level of the Immigration Appeal Board, to cope with the sharp increase. But that is not enough. The most immediate solution would lie in the immediate admission of all those claimants whom at present we will not return to their homes, that is, to those countries where civil strife exists and the repression of human rights is indubitable. (This would clearly exclude the Portuguese but would include the Tamils.) Such a policy, coupled with the additional admission of those who already have a support system in Canada, would reduce the backlog to reasonable proportions.

It has been said that such an approach rewards those who breach our set immigration procedures and "jump the queue". To this argument, I give two answers:

One is that queues exist for immigrants, not for refugees. The latter are by definition incapable of standing in line at our consulates and embassies, for they are fleeing for their lives. To be sure, not all claimants do, and a number of them will be found to have made insupportable submissions. But this can be ascertained only if the regular legal process so establishes it. By definition refugees do not fit our orderly requirements abroad, for they are the victims of disorderly conditions. Immigrants can wait their turn, refugees cannot.

The second one is that it must be understood that abuse of our present or any future system can never be totally avoided. We cannot build a Berlin wall around Canada, and even such a wall would be breached. At best we can make the process speedy enough so that a stay of only six months in Canada will not appear a worthwhile risk to the potential abuser.

\section{III}

Canada is an attractive land. We are on the whole an orderly society with great potential and a standard of living which is among the highest in the world. We have our warts, but they are small in comparison with our generally healthy complexion. People from other lands consider Canada a most desirable country in which to settle if the opportunity presents itself.

It seems to me that we ought to be happy with the high esteem we enjoy. Immigrants, like refugees who settle here, will benefit and not harm our society. They are most likely enterprising people willing to leave everything they know behind, to go to an unfamiliar world with a difficult climate. On arriving here, they will work hard and bring their determination to bear on our future. Good for them, and good for us.

We have quotas, or as the Department likes to call them, "immigration levels", which are determined by the Cabinet from year to year. These are ad hoc decisions, based on a number of economic factors, chief among them the level of unemployment.

Do the Department and the Cabinet arrive at their levels by way of a generally accepted, scientifically-based analysis? Are there other considerations that are at play, and what are they? Whom should we take and whom should we not admit? Are some parts of the world better than others as sources for Canadian immigration?

These and similar questions are not directly aspects of our refugee determination problem, but they are part of a larger picture and highlight the need for the government to let the public participate in a consideration of longrange population planning for this country. These issues and others were raised in Part II of my report, but so far the government has not released it to the public for consideration and discussion.

Meanwhile we have to deal with the immediate task of reforming our deformed present process. If it is done with ready humanity, rather than petulant hesitancy, we will not only earn the plaudits of the world but benefit the Canadian polity. For it is the kind of people we are, and not the wealth of our resources, that determines our future.

W. Gunther Plaut is Senior Scholar at Holy Blossom Temple, Toronto, and the author of Refugee Determination in Canada (published on April 17, 1985), a major report which served as a basis for legislation to be promulgated by the Federal Government in the coming months. Rabbi Plaut's most recent book is his first novel, The Letter, published by McClelland and Stewart. 